Sains Malaysiana 49(7)(2020): 1499-1508

http://dx.doi.org/10.17576/jsm-2020-4907-03

\title{
Effect of Abscisic Acid on Growth and Physiology of Arabica Coffee Seedlings under Water Deficit Condition
}

(Kesan Asid Absisik ke atas Pertumbuhan dan Fisiologi Anak Benih Kopi Arabica dalam Keadaan Kekurangan Air)

\author{
NGoc-Thang Vu, Jong-Man PARK, IL-Soep KIM, AnH-Tuan Tran \& Dong-Cheol JAnG*
}

\begin{abstract}
In this study, the effect of abscisic acid (ABA) on growth and physiology of Arabica coffee seedlings under water deficit condition was investigated. To examine the effect of ABA concentration on growth and physiology, six ABA concentrations $\left(0,10,50,100,150\right.$, and $\left.200 \mathrm{mgL}^{-1}\right)$ were applied by spraying once a day for three days. Additionally, the effect of ABA on physiology of Arabica coffee seedlings under water deficit condition was examined by using two concentrations (50 and $\left.100 \mathrm{mgL}^{-1}\right)$ compared to non-ABA $\left(0 \mathrm{mgL}^{-1}\right)$. Foliar application of ABA decreased the growth traits of coffee seedlings in all the ABA concentrations. However, no statically significant difference was observed among the 0, 10, 50, and $100 \mathrm{mgL}^{-1}$ treatments with growth traits except for the leaf area. Foliar application of ABA decreased the quantum efficiency of photosystem II $(\mathrm{Fv} / \mathrm{Fm})$ of Arabica coffee seedlings in watering condition. However, there was no significant difference between 0 (control) and $10 \mathrm{mgL} L^{-1}$ of $\mathrm{ABA}$ or 50 and $100 \mathrm{mgL}^{-1} \mathrm{or} 150$ and $200 \mathrm{mgL}^{-1}$ of ABA treatment with the Fv/Fm. The application of ABA enhanced drought tolerance of coffee seedlings by increasing the leaf chlorophyll content, $F v / F m$ and relative water content in the leaf and reducing the relative ion leakage in the Arabica coffee seedlings. The application of ABA increased the relative water content in the soil and delayed the starting time of wilting point under water deficit condition.
\end{abstract}

Keywords: Abscisic acid; coffee; growth; physiology; water stress

ABSTRAK

Dalam kajian ini, kesan asid absisik (ABA) terhadap pertumbuhan dan fisiologi anak benih kopi Arabica dalam keadaan kekurangan air telah dikaji. Bagi mengkaji kesan kepekatan ABA terhadap pertumbuhan dan fisiologi anak benih kopi ini, enam kepekatan $A B A$ (0, 10, 50, 100, 150 dan $\left.200 \mathrm{mgL} \mathrm{L}^{-1}\right)$ telah digunakan dengan penyemburan sekali sehari selama tiga hari. Selain itu, kesan ABA terhadap fisiologi anak benih kopi dalam keadaan kekurangan air telah dikaji menggunakan dua kepekatan (50 dan $100 \mathrm{mgL}^{-1}$ ) dan dibandingkan dengan benih tiada-ABA (0 mgL-1). Semburan daun ABA telah mengurangkan sifat pertumbuhan anak benih kopi pada semua kepekatan ABA. Walau bagaimanapun, tidak terdapat perbezaan yang signifikan secara statistik pada ciri pertumbuhan benih antara rawatan ABA 0, 10, 50 dan $100 \mathrm{mgL}^{-1}$ kecuali pada kawasan daun. Semburan daun ABA menurunkan kecekapan kuantum fotosistem II (Fv / Fm) benih kopi Arabica yang diairkan. Walau bagaimanapun, tidak ada perbezaan yang signifikan antara kepekatan rawatan ABA $0 \mathrm{mgL}^{-1}$ (kawalan) dan $10 \mathrm{mgL}^{-1}$ atau 50 dan $100 \mathrm{mgL}^{-1}$ atau 150 dan $200 \mathrm{mgL}^{-1}$ dengan Fv/Fm. Penggunaan ABA telah meningkatkan ketahanan anak benih kopi terhadap kekeringan dengan meningkatkan kandungan klorofil, Fv/Fm dan kandungan air relatif di dalam daun, serta mengurangkan kebocoran ion relatif benih kopi Arabica. Penggunaan ABA juga telah meningkatkan kandungan air relatif di dalam tanah dan melambatkan waktu mula titik layu dalam keadaan kekurangan air.

Kata kunci: Asid absisik; fisiologi; ketegasan air; kopi; pertumbuhan

\section{INTRODUCTION}

Coffee is one of the most important agricultural products in the international market. It is cultivated in different latitudes around the world, but its distribution depends on many factors, such as climate, location, soil types, shading and management practices (Wintgens 2004). Among approximately 100 Coffea species, Coffea arabica and
Coffea canephora var. robusta economically dominate the world coffee trade and being responsible for $98-99 \%$ of the world's coffee bean production. Minor species include Coffea liberica and Coffea excels, which are mainly restricted to West Africa and Asia, and account for only $1-2 \%$ of the global production (Wintgens 2004). Presently, Arabica coffee accounts for $62 \%$ of coffee consumed, and Robusta coffee for the rest. 
Drought is an environment factor that causes water deficit or stress in coffee plants (Pinheiro et al. 2005). Drought-stress and unfavorable temperatures are considered to be the major environmental factors limiting coffee plant growth and yield in most coffee growing areas (DaMatta \& Ramalho 2006). These limitations are expected to become increasingly important in several coffee growing regions due to the recognized changes in the global climate. Moreover, coffee cultivation has spread towards marginal lands, where water shortage and unfavorable temperatures constitute the major constraints to coffee yield (DaMatta \& Ramalho 2006).

Abscisic acid (ABA) is a very important agent in the mechanisms of resistance and adaptation in plants against various abiotic stress conditions (Bakhsh et al. 2011; Li et al. 2010; Vu et al. 2015). It plays an essential role in many physiological processes, including seed development, dormancy, germination, and reproduction (Finkelstein et al. 2002; Planes et al. 2015). In addition, it plays a pivotal role in abiotic stress tolerance (Leung \& Giraudat 1998). ABA mediates responses to environmental stresses, such as heat, cold, salt, drought, and high irradiance (Cousson 2009; Larkindale \& Knight 2002; Pospisilova et al. 2009; Taylor et al. 2000). Therefore, the objectives of this study were to evaluate the enhanced drought tolerance of Arabica coffee seedlings by application of ABA in order to improve the growth and physiology of coffee seedlings during the transplanting period from nursery to farm.

\section{MATERIALS AND METHODS}

\section{PLANT MATERIAL AND SOIL CONDITION}

The seeds of Arabica coffee were sown in a plastic bag that had been filled with mountain soil. One month after germination, the seedlings were fertilized at an overhead irrigation once a week with modified Hoagland solution (Hoagland \& Arnon 1950). Three months after germination, the seedlings were transferred to pots (with top and bottom diameters of $15 \mathrm{~cm}$ and $12 \mathrm{~cm}$, respectively; depth of $13 \mathrm{~cm}$; and 8 bottom perforations), which were filled with $3 \mathrm{~kg}$ mountain soil. Two months after transplanting to plastic pots, the plants were used for treating. The soil for this experiment was obtained from the mountain at Son La province of Vietnam country. The chemical properties and particle sizes of soil used in this study are shown in Table 1.

\section{ABA APPLICATION AND WATER STRESS TREATMENT}

Two experiments were carried out in a plastic house at the Vietnam National University of Agriculture. The effect of ABA concentrations on growth and physiology of coffee seedlings in the watering condition was examined. Two months after transplanting to plastic pots, five $\mathrm{ABA}$ concentrations $(10,50,100,150$, and 200 $\mathrm{mgL}^{-1}$ ) and control (non-ABA) were applied by spraying once a day for 3 days. This experiment was arranged in a completely randomized design with 60 plants for one treatment in three replications. In this experiment, the Fv/ Fm parameter was measured after 10 days of treatment under plastic house condition. One month after treatment, ten seedlings per treatment were randomly selected for determination of growth traits, such as plant height $(\mathrm{cm})$, leaf length $(\mathrm{cm})$, leaf width $(\mathrm{cm})$, leaf area $\left(\mathrm{dm}^{2}\right)$, leaf chlorophyll content (SPAD), fresh and dry weight of shoots and roots $(\mathrm{g})$. The leaf area was measured by leaf area meter (Delta-T Device Ltd., Burwell, Cambridge, UK). The leaf chlorophyll content was measured using a chlorophyll meter (SPAD-502 Plus, Konica Minolta Sensing Inc., Osaka, Japan). The fresh shoots and roots were dried in an oven (MOV-212F, Sanyo Electric Co., Ltd., Osaka, Japan) at $80{ }^{\circ} \mathrm{C}$ for $72 \mathrm{~h}$ before measuring the dry matter.

The effect of ABA concentrations on the physiology of Arabica coffee seedlings in a water deficit condition was carried. In order to investigate the tolerance to drought stress, two months after transplanting to plastic pots, the coffee seedlings were applied by spraying once a day for 3 days with 0 (control), 50 and $100 \mathrm{mgL}^{-1}$ of ABA. The coffee seedlings were fully irrigated with water after spraying, and then the irrigation was withheld until wilted seedlings were observed. For the individual physiology traits, the wilted seedlings were treated with and without re-watering. This experiment was arranged in a completely randomized design with 90 plants for one treatment in three replications. Physiology parameters, such as leaf chlorophyll content and Fv/Fm, were measured in treated plants from without watering to five days after re-watering. Six days after without watering and one month after re-watering, the coffee seedlings were harvested for analysis of relative water content in the leaf and relative ion leakage. A percentage of the wilted plants was measured in 30 seedlings per treatment until night day after without watering. For the relative water content in soil measurement, $24 \mathrm{~h}$ after treatment, eight pots of each treatment were covered with vinyl film to prevent water loss from the soil.

A portable fluorometer (model OS-30p; OptiSciences Chlorophyll Fluorometer, Hudson, USA) was used to measure the initial fluorescence $\left(\mathrm{F}_{0}\right)$, maximum fluorescence $(\mathrm{Fm})$ and potential quantum efficiency of photosystem II (Fv/Fm). From these fluorescence data, the following parameters were calculated: Variable fluorescence $\left(\mathrm{Fv}=\mathrm{Fm}-\mathrm{F}_{0}\right)$ and effective absorbed energy conversion efficiency of photosystem II $\left(\mathrm{Fv} / \mathrm{F}_{0}\right)$. Fluorescence determinations were performed between 08:00 $\mathrm{h}$ and 11:00 $\mathrm{h}$ on the same leaves used to evaluate 
the gas exchanges. They were then submitted to a $30 \mathrm{~min}$ dark adaptation period using leaf-clip holders, so that all the reaction centers in that foliar region acquired the 'open' configuration, indicating complete oxidation of the photosynthetic electron transport system.

Relative water content in the leaf (RWC) was assessed from the leaves of eight seedlings of similar sizes. The leaves were taken from the youngest fully expanded leaves. Ten leaf discs per plant were made up. Leaf discs were immediately weighed (fresh weight; FW). These samples were floated in distilled water inside the porous platform, in order to obtain turgid weight (TW) at a temperature range of $25-30{ }^{\circ} \mathrm{C}$. At the end of the imbibition period, leaf samples were placed in a preheated oven at $80^{\circ} \mathrm{C}$ for $48 \mathrm{~h}$ in order to obtain dry weight (DW). Values of FW, TW and DW were used to calculate RWC, by using (1):

$$
R W C(\%)=\frac{F W-D W}{T W-D W} \times 100
$$

Relative ion leakage was also assessed by the leakage of electrolytes from the leaves of eight seedlings of similar size. Leakage of electrolytes was determined by using a conductivity meter (AG 8603, SevenEasy, Mettler Toledo, Switzerland). The leaf segments (disks of leaves with $\mathrm{d}=1 \mathrm{~cm}^{2}$ ) were washed, blotted dry, weighted and put in stopped vials filled with the exact volume of deionized water. The vials were then incubated for $2 \mathrm{~h}$ in darkness with continuous shaking, and then conduction $\left(\mathrm{C}_{1}\right)$ was measured. The vials were heated at $80{ }^{\circ} \mathrm{C}$ for $2 \mathrm{~h}$ and conduction $\left(\mathrm{C}_{2}\right)$ was measured again. The electrolyte leakage was expressed as a percentage of the relative ion leakage, which was calculated according to the equation (2) (Zhao et al. 2007):

Relative electrolyte leakage $(\%)=\frac{C_{1}}{C_{2}} \times 100 \%$

For the relative water content in the soil measurement, the potted seedlings covered with vinyl film were weighed daily. The decrease in pot weight was used as an estimate of relative water content. Percentage of wilted plant in drought stress were calculated when $75 \%$ of leaves per seedling withered.

\section{DATA ANALYSIS}

Data were analyzed by using the SAS v.9.3 software (SAS Institute Inc., Cary, NC, USA). The mean separations were calculated by using the Duncan's multiple range tests at $P \leq 0.05$.

\section{RESULTS AND DISCUSSION}

\section{EFFECT OF ABA ON GROWTH AND PHYSIOLOGY OF SEEDLINGS IN WATERING CONDITION}

Inhibition of plant growth by ABA has been reported in many papers (Alves \& Setter 2000; Carrow 1996; Sharp et al. 1994; Vu et al. 2015). In this experiment, the plant height, leaf length and width of coffee seedlings decreased with increasing ABA concentration (Table 2). The highest values of the plant height, leaf length and width were observed in the control treatment $\left(0 \mathrm{mgL}^{-1}\right)$, but not statically different for seedlings treated with 10 , 50 , and $100 \mathrm{mgL}^{-1}$ of ABA. There were not statistically different between the control and $10 \mathrm{mgL}^{-1}$ of ABA with leaf area. However, the leaf area decreased significantly in seedlings treated with 50,100,150, and $200 \mathrm{mgL}^{-1}$ of ABA (Table 2). On other hand, leaf chlorophyll content also decreased with increasing ABA concentration. However, no statistically difference was shown among $0,10,50,100,150$, and $200 \mathrm{mgL}^{-1}$ of ABA. This result agrees with those of Farooq and Bano (2006) in mung bean plants and $\mathrm{Vu}$ et al. (2015) in tomato plant. They also showed that the application of ABA causes a decrease in the chlorophyll content in plants.

After one month treating with ABA, the fresh and dry weight of shoots, leaves, and roots of the coffee seedlings decreased with increasing ABA concentration. This result agrees with previously reported data that ABA generally inhibits shoot and root growth (Munns \& Cramer 1996; Vu et al. 2015). Although the fresh and dry weight of shoots, leaves, and roots of coffee seedlings decreased with increasing ABA concentration. However, there was no statistical difference among the $0,10,50$, and $100 \mathrm{mgL}^{-1}$ treatments for fresh and dry weight of the shoots, leaves and roots. The lowest values of fresh and dry weight of the shoots, leaves and roots were obtained in $200 \mathrm{mgL}^{-1}$ treatment, but they were not statistical different from the $150 \mathrm{mgL}^{-1}$ treatment. The highest values of the fresh and dry weight of the shoots, leaves and roots were obtained in the non-ABA treatment (0 $\left.\mathrm{mgL}^{-1}\right)$ (Table 3$)$.

In the watering condition, the quantum efficiency of photosystem II ( Fv/Fm) decreased with increasing ABA concentration (Figure 1). This result agrees with that of Sewelam et al. (2017) in Triticum aestivum seedlings, which also showed that the application of ABA caused decreases in $\mathrm{Fv} / \mathrm{Fm}$. In this experiment, the highest value of Fv/Fm (0.81) was observed in the control treatment, but it was not statistically significant with $10 \mathrm{mgL}^{-1}$ of $\mathrm{ABA}$. The lowest value of $\mathrm{Fv} / \mathrm{Fm}$ 
(0.775) was observed in $200 \mathrm{mgL}^{-1}$ of ABA. However, it was not statistically significant with $150 \mathrm{mgL}^{-1}$ of ABA. There was also no significant difference between 50 and $100 \mathrm{mgL}^{-1}$ of $\mathrm{ABA}$ treatment for $\mathrm{Fv} / \mathrm{Fm}$.

\section{EFFECT OF ABA ON PHYSIOLOGY OF SEEDLINGS IN WATER DEFICIT CONDITION}

The effect of ABA concentrations on the chlorophyll content of coffee seedlings is shown in Figure 2. Significant difference was shown in the chlorophyll content of three treatments in water stress and after re-watering periods. The chlorophyll contents of all the treatments significantly decreased with increasing duration of treating water stress. However, the chlorophyll content of all the treatments significantly increased with increasing duration after re-watering. In the water deficit condition, the lowest value of chlorophyll content was observed in control. The highest value of chlorophyll content was observed in $100 \mathrm{mgL}^{-1}$ of $\mathrm{ABA}$, but it was similar to that of $50 \mathrm{mgL}^{-1}$ of ABA. This result agrees with that of Anbarasi et al. (2015) in Suaeda maritima plant, which also showed that the application of ABA increased the chlorophyll a, chlorophyll b and total chlorophyll.

The quantum efficiency of photosystem II (Fv/Fm) of all treatments decreased significantly with increased water deficit duration (Figure 3). However, the lowest value of Fv/Fm was observed in the control. The highest value of $\mathrm{Fv} / \mathrm{Fm}$ was observed in $100 \mathrm{mgL}^{-1}$ of $\mathrm{ABA}$, but it was similar to that of $50 \mathrm{mgL}^{-1}$ of ABA. After rewatering, the Fv/Fm of all the treatments significantly increased with increasing duration time. However, the higher values of the Fv/Fm were also observed in the ABA treatments. This result agrees with that of Wang et al. (2010) in cucumber seedlings, which also showed that the application of ABA pre-treatment caused an increase of FV/Fm in the water deficit condition. Therefore, in the water stress condition, the Fv/Fm values of coffee plants in ABA treatments were higher than that in the control in both water stress and after re-watering periods.

Relative water content in leaves is contemplated as a potential indicator of plant water status because it is involved in the metabolic activity in tissues. Decline in relative water content in leaves reflects a loss of turgor that results in limited cell expansion and thereby reduced growth in crop plants (Ashraf 2010; Lu et al. 2010). In this study, ABA application induced an increase in relative water content in the leaves of coffee seedlings under water stress condition (Figure 4). These results are in agreement with those of Agarwal et al. (2005) who reported that exogenous application of ABA increased the relative water content in the leaves in wheat under water stress. In addition, a higher value of relative water content in the leaves after pretreatment with ABA has been also recorded for other plants, such as tall fescue (Jiang \& Huang 2002), tobacco (Pospisilova et al. 2005) and tomato (Vu et al. 2015). Therefore, in this study,
ABA application induced an increase in relative water content in the leaf of coffee seedlings in drought stress. The highest value of relative water content in the leaf was observed in $100 \mathrm{mgL}^{-1}$ of $\mathrm{ABA}$, and it was similar than that of $50 \mathrm{mgL}^{-1} \mathrm{ABA}$. Although the relative water content in the leaf of the control increased after one-month rewatering, but it was still lower than that of 50 and 100 $\mathrm{mgL}^{-1}$ of $\mathrm{ABA}$ treatments.

Electrolyte leakage is another component connected with different abiotic stresses. In this study, we found that ABA treatment led to a significant decrease in the relative ion leakage (Figure 5). These results are in agreement with those of Hala and Ghada (2009), who reported that foliar spraying of wheat plants with 50 and $100 \mu \mathrm{M} \mathrm{ABA}$ decreased the percentage of relative ion leakage in severe stressed plants. On the other hand, Vu et al. (2015) also showed that the application of ABA enhanced stress tolerance (cold and drought) of tomato seedlings by reducing the relative ion leakage. In this study, the highest value of relative ion leakage was observed in the control treatment. The lowest value of relative ion leakage was observed in $100 \mathrm{mgL}^{-1}$ of $\mathrm{ABA}$, and it was similar to that of $50 \mathrm{mgL}^{-1}$ treatments. Although relative ion leakage in the control decreased after one-month re-watering, it was still higher than that of 50 and $100 \mathrm{mgL}^{-1}$ of ABA.

The relative water content significantly decreased during the period without irrigation. However, relative water content increased with increasing ABA concentration (Figure 6). The ABA application enhanced drought tolerance of coffee seedlings by delaying the start time of wilting point. In the control, the start time of the wilting point was observed on the 6th day. However, in 50 and $100 \mathrm{mgL}^{-1}$ of $\mathrm{ABA}$, the start times of wilting point were observed on the 8 th and 9 th day without irrigation, respectively.

ABA is known to protect plants from drought damage by inducing stomata closure to reduce water loss via transpiration (Borel et al. 1997; Li et al. 2000) and increasing hydraulic conductance for water movement from roots to leaves (Ludewig et al. 1988; Zhang et al. 1995). Likewise, in our study, the application of ABA enhanced the drought tolerance of coffee plants by delaying the starting time of the wilting point under water stress condition (Table 4). This result agrees with other studies to report that ABA improved drought tolerance Pinus banksiana (Rajasekaran \& Blake 1999), Tradescantia virginiana (Frank \& Farquhar 2001) and Lycopersicon esculentum ( $\mathrm{Vu}$ et al. 2015). In addition, the study of both spray and drench applications of 500 $\mathrm{mgL}^{-1} \mathrm{ABA}$ on a variety of popular bedding plants demonstrated a delayed time to wilting from 3 days in marigolds to 4 days in petunia (Waterland et al. 2010). Likewise, in the study of tomato, ABA has shown to enhance drought tolerance of seedlings by delaying the start time of wilting point from day 3 in the control to day 5 and 7 in the 50 and $100 \mathrm{mgL}^{-1} \mathrm{ABA}$ treatments $(\mathrm{Vu}$ et al. 2015). 
TABLE 1. The chemical properties and particle size of soil in this study

\begin{tabular}{|c|c|c|}
\hline Parameters & & The chemical properties and particle size \\
\hline \multirow{3}{*}{ Particle size distribution in soil material (\%) } & $2-0.02$ & 28.60 \\
\hline & $0.02-0.002$ & 42.70 \\
\hline & $<0.002$ & 28.70 \\
\hline $\mathrm{OC}(\%)$ & & 0.97 \\
\hline Humic $(\%)$ & & 0.43 \\
\hline $\mathrm{pH}_{\mathrm{KCl}}$ & & 5.10 \\
\hline $\mathrm{N}(\mathrm{mg} / 100 \mathrm{~g})$ & & 0.97 \\
\hline $\mathrm{P}_{2} \mathrm{O}_{5}(\mathrm{mg} / 100 \mathrm{~g})$ & & 0.43 \\
\hline $\mathrm{K}_{2} \mathrm{O}(\mathrm{mg} / 100 \mathrm{~g})$ & & 10.90 \\
\hline $\mathrm{Ca}^{2+}(\mathrm{mg} / 100 \mathrm{~g})$ & & 0.70 \\
\hline $\mathrm{Mg}^{2+}(\mathrm{mg} / 100 \mathrm{~g})$ & & 2.33 \\
\hline $\mathrm{Fe}^{3+}(\mathrm{mg} / 100 \mathrm{~g})$ & & 34.60 \\
\hline $\mathrm{Cl}^{-}(\mathrm{mg} / 100 \mathrm{~g})$ & & 8.16 \\
\hline $\mathrm{Mg}^{2+}(\mathrm{mg} / 100 \mathrm{~g})$ & & 80.30 \\
\hline $\mathrm{Zn}^{2+}(\mathrm{mg} / 100 \mathrm{~g})$ & & 3.20 \\
\hline $\mathrm{Cu}^{2+}(\mathrm{mg} / 100 \mathrm{~g})$ & & 61.10 \\
\hline
\end{tabular}

TABLE 2. Effect of ABA concentrations on growth characteristics of Arabica coffee seedlings in the watering condition

\begin{tabular}{|c|c|c|c|c|c|}
\hline $\begin{array}{l}\text { ABA } \\
\text { concentration } \\
\left(\mathrm{mgL}^{-1}\right)\end{array}$ & $\begin{array}{c}\text { Plant } \\
\text { height }(\mathrm{cm})\end{array}$ & $\begin{array}{l}\text { Leaf length } \\
\quad(\mathrm{cm})\end{array}$ & $\begin{array}{l}\text { Leaf width } \\
\text { (cm) }\end{array}$ & $\begin{array}{l}\text { Leaf area } \\
\left(\mathrm{dm}^{2}\right)\end{array}$ & $\mathrm{SPAD}^{\mathrm{z}}$ \\
\hline 0 (Control) & $20.03 \mathrm{a}$ & $9.65 \mathrm{a}$ & $6.24 \mathrm{a}$ & $3.67 \mathrm{a}$ & $45.5 \mathrm{a}$ \\
\hline 10 & $19.97 \mathrm{a}$ & $9.55 \mathrm{a}$ & $6.10 \mathrm{a}$ & $3.33 \mathrm{ab}$ & $45.1 \mathrm{a}$ \\
\hline 50 & $19.33 \mathrm{ab}$ & $9.34 \mathrm{ab}$ & $5.84 \mathrm{ab}$ & $3.18 \mathrm{~b}$ & $45.6 \mathrm{a}$ \\
\hline 100 & $19.02 \mathrm{~b}$ & $9.23 \mathrm{ab}$ & $5.81 \mathrm{ab}$ & $3.11 \mathrm{~b}$ & $45.7 \mathrm{a}$ \\
\hline 150 & $18.45 \mathrm{~b}$ & $9.12 \mathrm{~b}$ & $5.31 \mathrm{~b}$ & $2.96 \mathrm{c}$ & $43.8 \mathrm{a}$ \\
\hline 200 & $18.15 \mathrm{~b}$ & $9.08 \mathrm{~b}$ & $5.21 \mathrm{~b}$ & $2.72 \mathrm{c}$ & $43.5 \mathrm{a}$ \\
\hline
\end{tabular}


TABLE 3. Effect of ABA concentrations on fresh weight and dry weight of shoots, leaves and roots of Arabica coffee seedlings in the watering condition

\begin{tabular}{lcccccc}
\hline \multirow{2}{*}{$\begin{array}{l}\text { ABA } \\
\text { concentration } \\
(\mathrm{mg} / \mathrm{L})\end{array}$} & Shoot & Leaf & Root & Shoot & Leaf & Root \\
\cline { 2 - 6 } $0($ Control $)$ & $3.13 \mathrm{a}$ & $7.59 \mathrm{a}$ & $4.73 \mathrm{a}$ & $1.18 \mathrm{a}$ & $2.02 \mathrm{a}$ & $1.40 \mathrm{a}$ \\
10 & $3.08 \mathrm{a}$ & $7.56 \mathrm{a}$ & $4.60 \mathrm{a}$ & $1.15 \mathrm{a}$ & $2.01 \mathrm{a}$ & $1.40 \mathrm{a}$ \\
50 & $2.85 \mathrm{ab}$ & $7.16 \mathrm{ab}$ & $4.26 \mathrm{ab}$ & $1.05 \mathrm{ab}$ & $1.92 \mathrm{ab}$ & $1.25 \mathrm{ab}$ \\
100 & $2.78 \mathrm{ab}$ & $7.02 \mathrm{ab}$ & $4.12 \mathrm{ab}$ & $1.02 \mathrm{ab}$ & $1.90 \mathrm{ab}$ & $1.24 \mathrm{ab}$ \\
150 & $2.52 \mathrm{~b}$ & $6.82 \mathrm{~b}$ & $3.87 \mathrm{~b}$ & $0.83 \mathrm{~b}$ & $1.77 \mathrm{~b}$ & $1.12 \mathrm{~b}$ \\
200 & $2.37 \mathrm{~b}$ & $6.26 \mathrm{~b}$ & $3.12 \mathrm{~b}$ & $0.72 \mathrm{~b}$ & $1.61 \mathrm{~b}$ & $1.03 \mathrm{~b}$ \\
\hline
\end{tabular}

TABLE 4. Effect of ABA concentrations on percentage of wilted plant of Arabica coffee seedlings after without irrigation

\begin{tabular}{lccccccccc}
\hline \multirow{2}{*}{$\begin{array}{l}\text { ABA } \\
\text { concentration } \\
\left(\mathrm{mgL}^{-1}\right)\end{array}$} & \multicolumn{8}{c}{ Percentage of wilted plant after without irrigation (\%) } \\
\cline { 2 - 7 } & $\begin{array}{l}\text { First } \\
\text { day }\end{array}$ & Second day & Third day & $\begin{array}{c}\text { Fourth } \\
\text { day }\end{array}$ & $\begin{array}{c}\text { Fifth } \\
\text { day }\end{array}$ & Sixth day & Seventh day & $\begin{array}{c}\text { Eighth } \\
\text { day }\end{array}$ & Ninth day \\
\hline 0 (control) & 0.0 & 0.0 & 0.0 & 31.5 & 75.7 & 100.0 & - & - & - \\
50 & 0.0 & 0.0 & 12.5 & 37.5 & 45.5 & 57.8 & 74.6 & 100.0 & - \\
100 & 0.0 & 0.0 & 0.0 & 18.8 & 43.8 & 50.3 & 65.8 & 85.7 & 100.0 \\
\hline
\end{tabular}

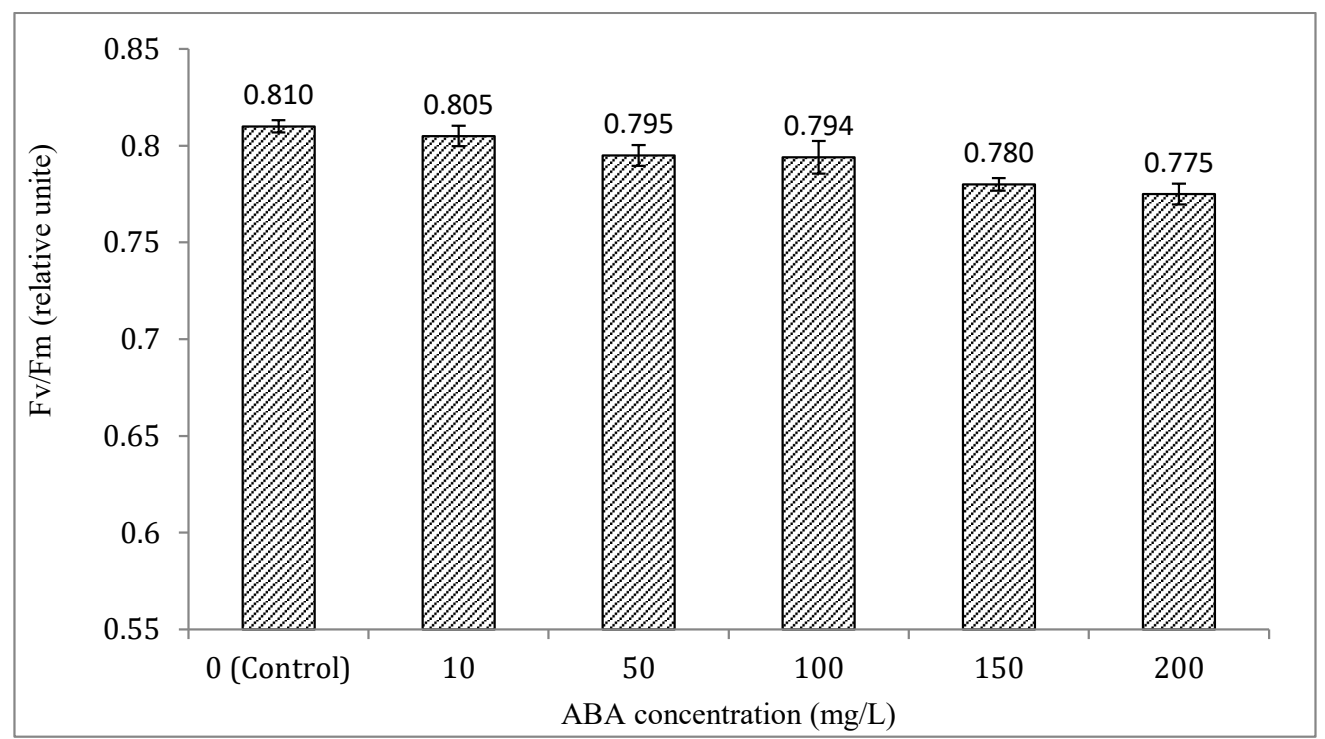

FIGURE 1. Effect of ABA concentrations on the quantum efficiency of photosystem II of Arabica coffee seedlings in the watering condition. Vertical bars represent $\pm \mathrm{SD}, \mathrm{n}=10$ 


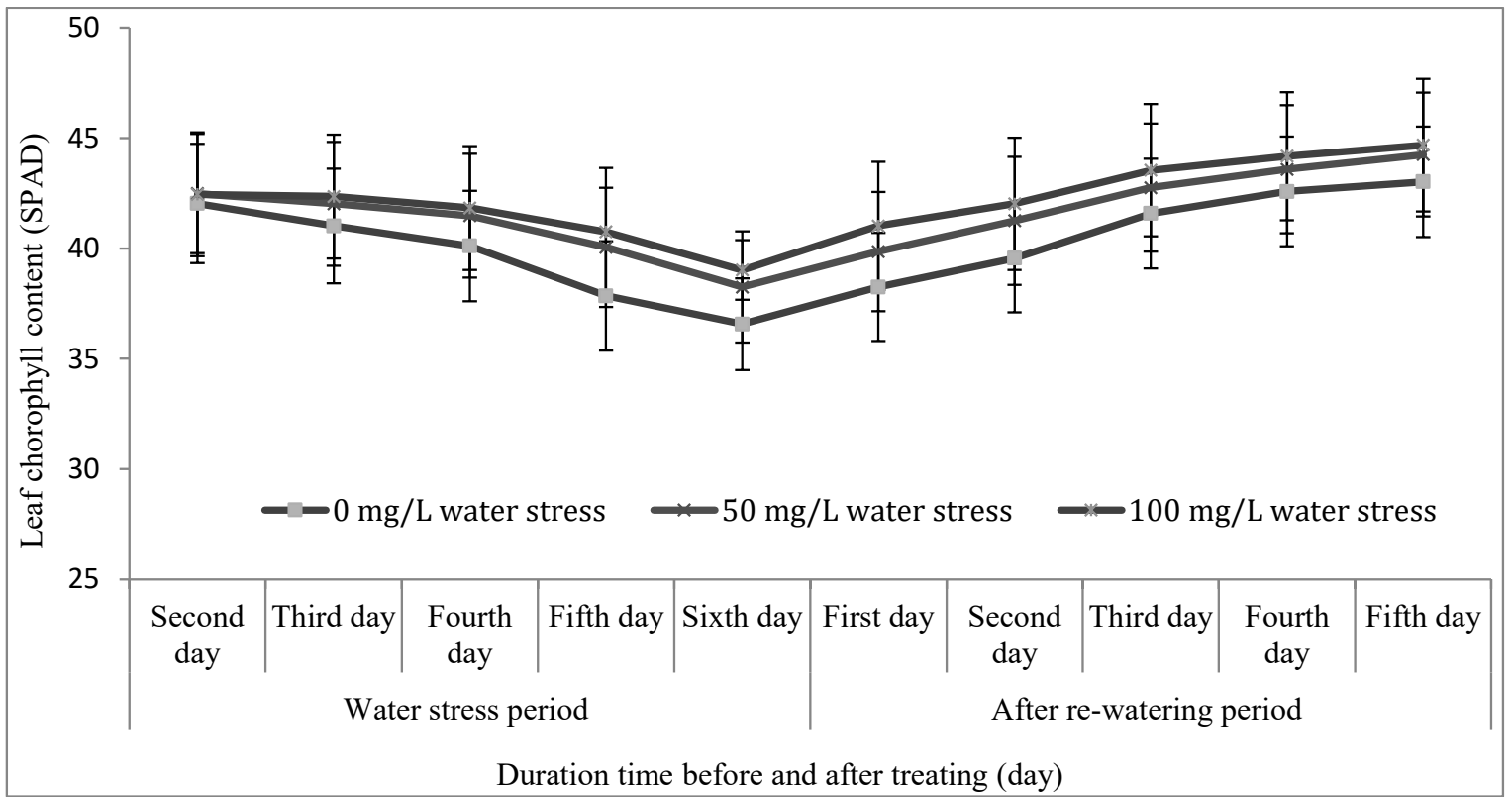

FIGURE 2. Effect of ABA concentrations on leaf chlorophyll content of Arabica coffee seedlings in water deficit condition. Vertical bars represent $\pm \mathrm{SD}, \mathrm{n}=10$

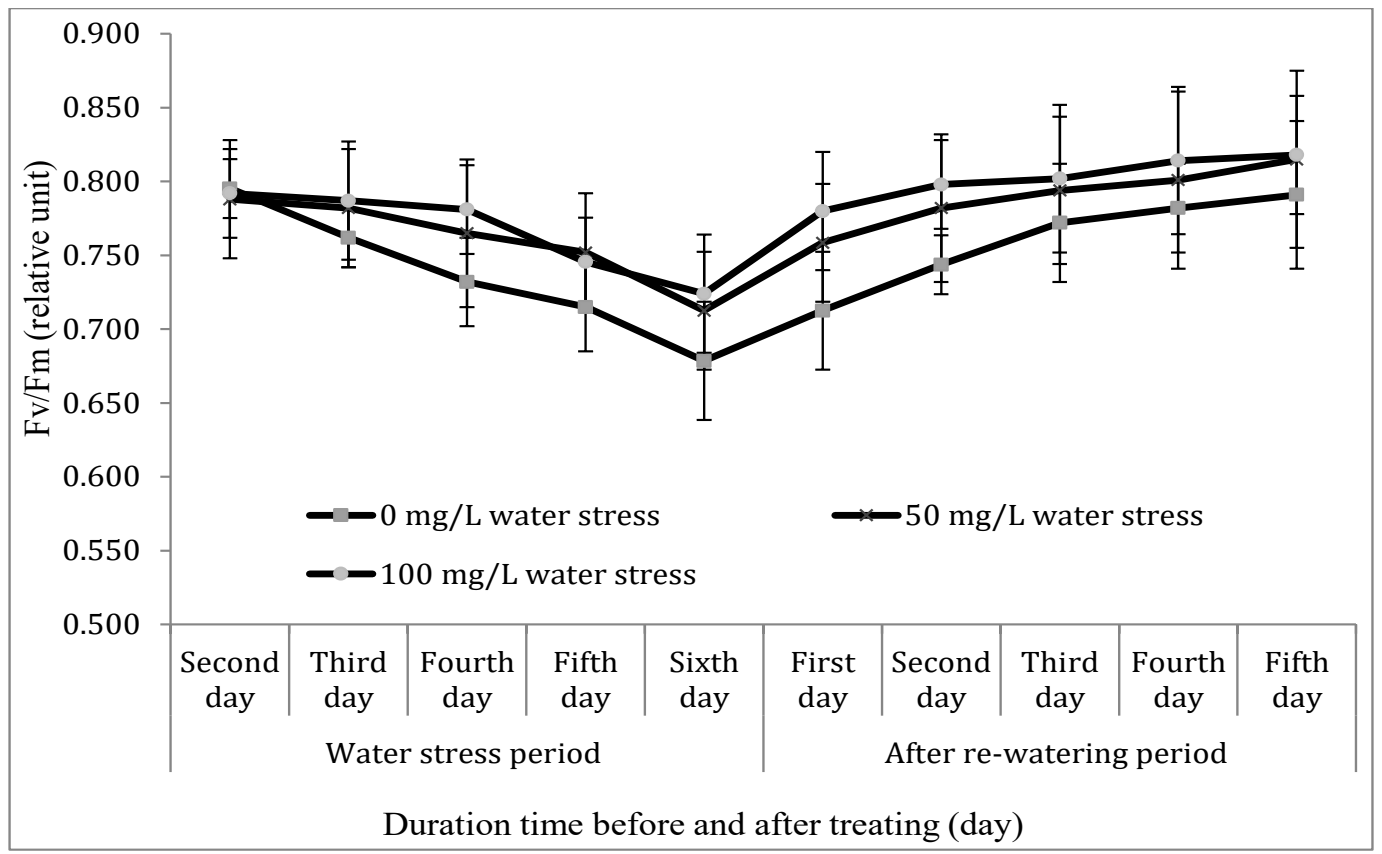

FIGURE 3. Effect of ABA concentrations on the quantum efficiency of photosystem II $(\mathrm{Fv} / \mathrm{Fm})$ of Arabica coffee seedlings in water deficit condition. Vertical bars represent \pm

$$
\text { SD. } n=10
$$




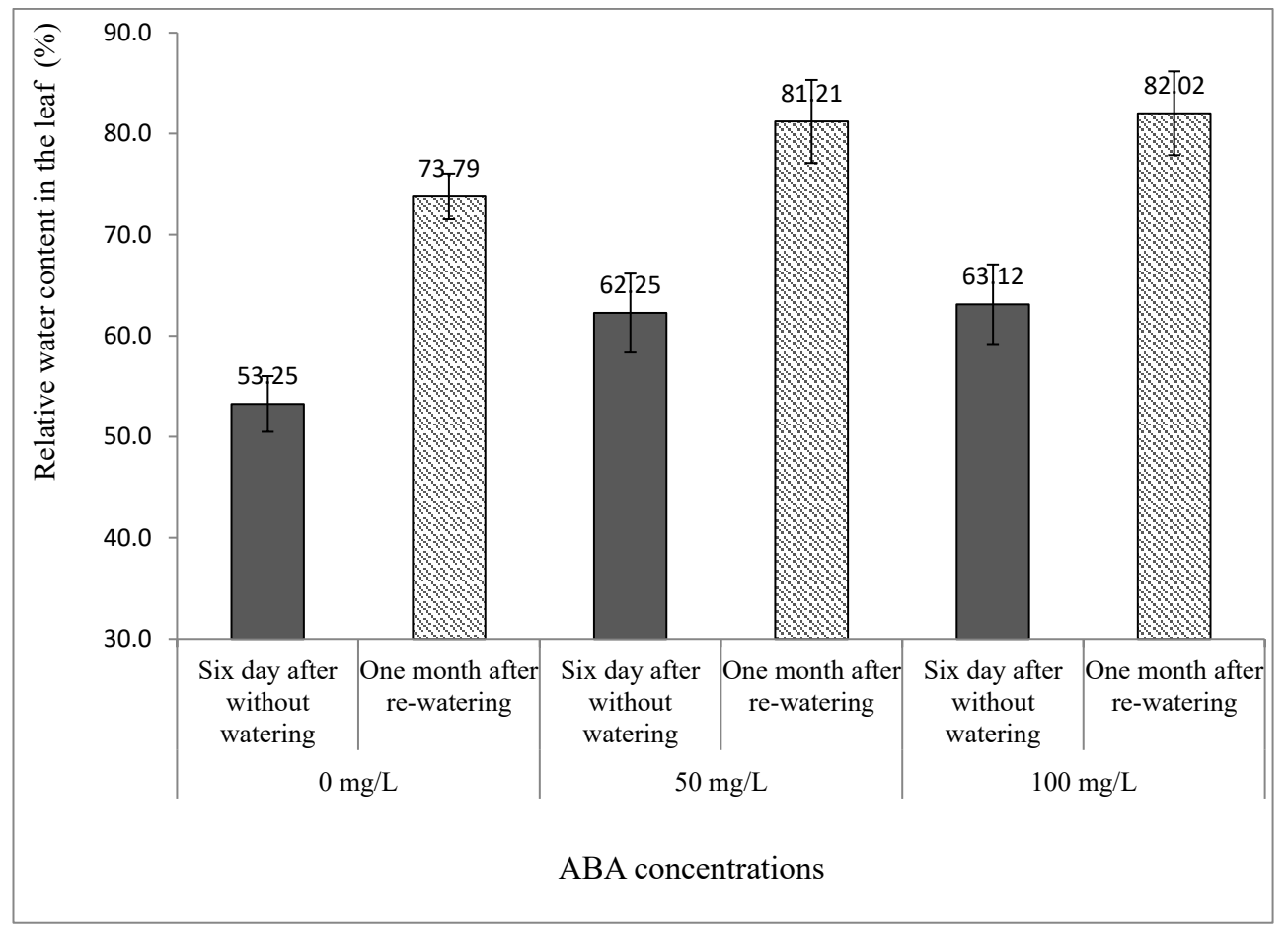

FIGURE 4. Effect of ABA concentrations on relative water content in the leaf of Arabica coffee seedlings in water deficit condition. Vertical bars represent \pm SD, $n=8$

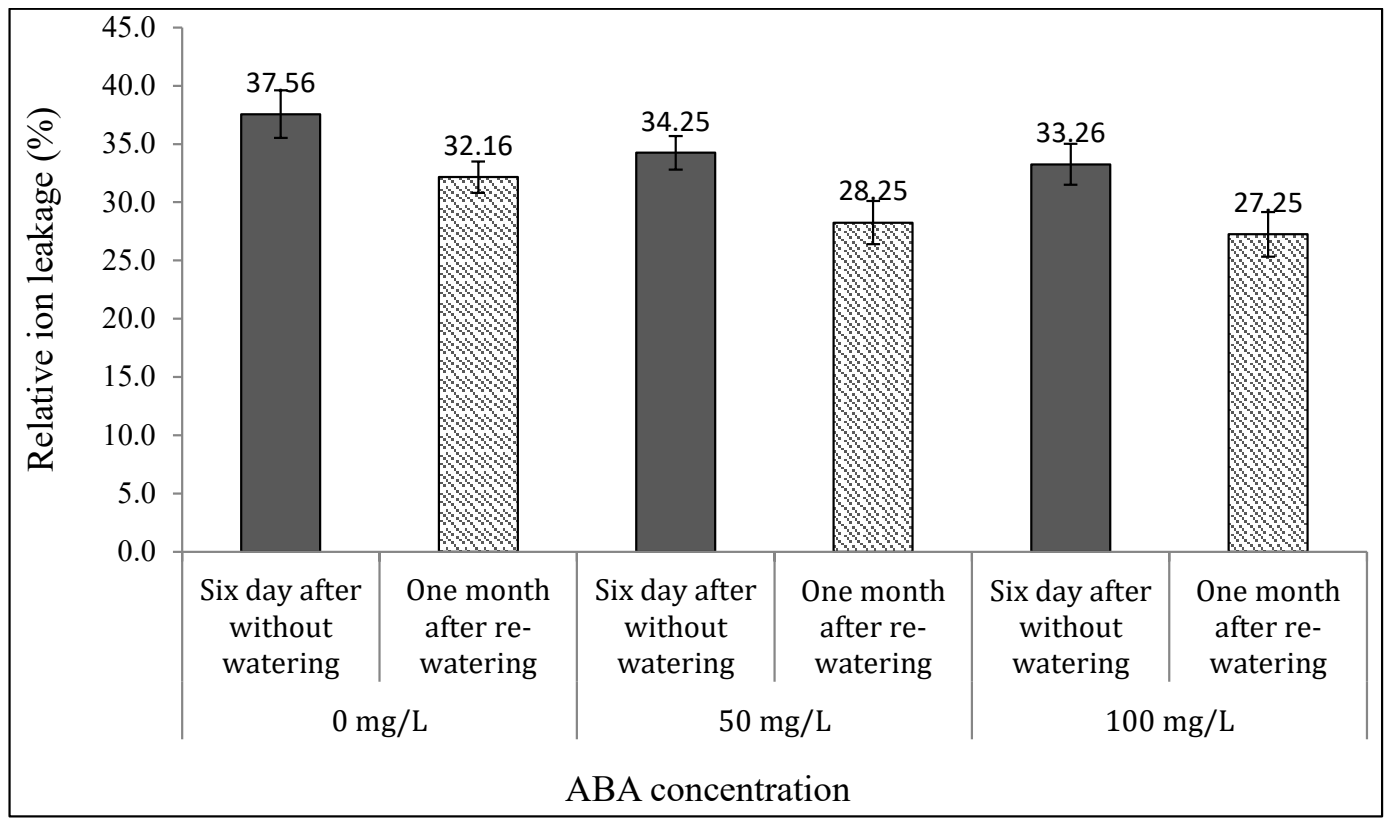

FIGURE 5. Effect of ABA concentrations on relative ion leakage of Arabica coffee seedlings in water deficit condition. Vertical bars represent $\pm \mathrm{SD}, \mathrm{n}=8$ 


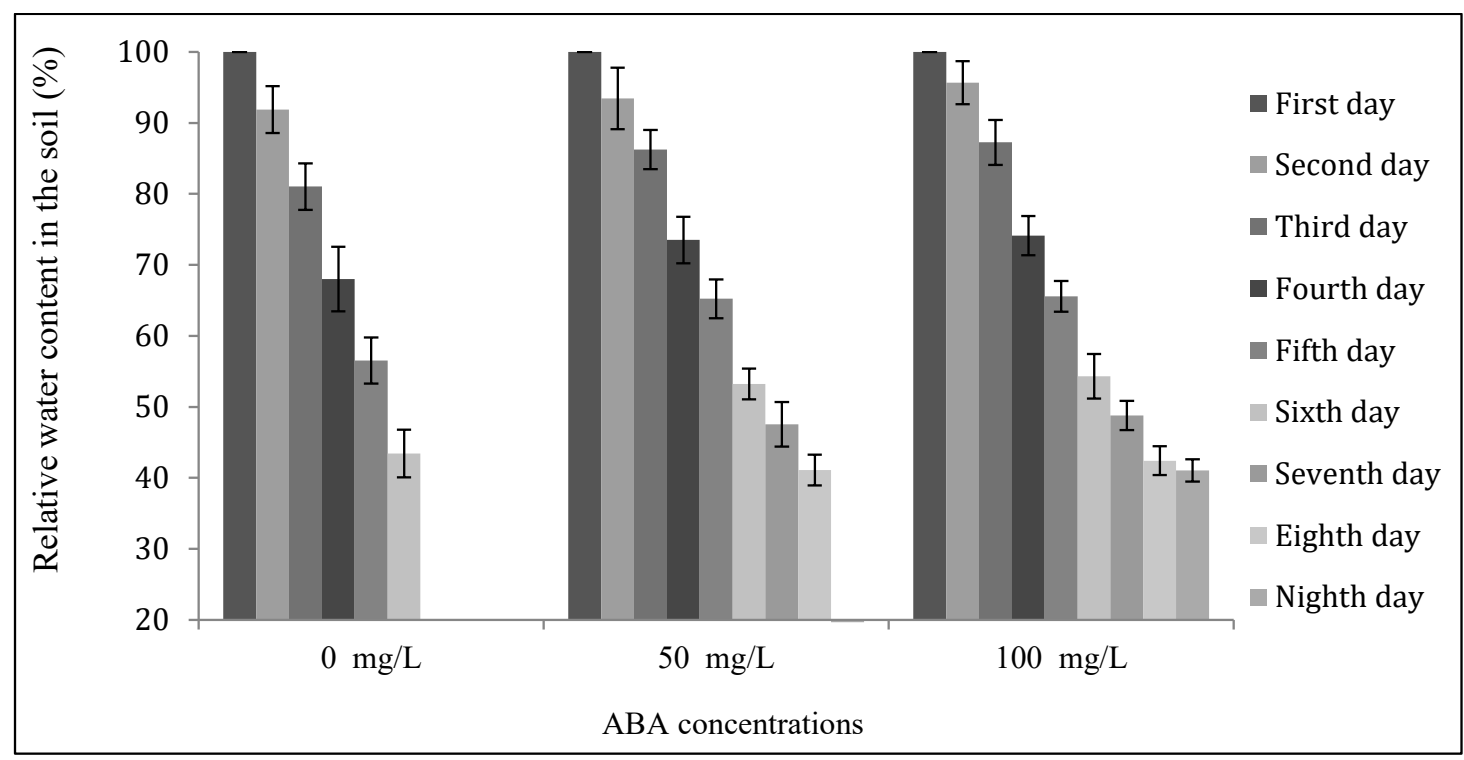

FIGURE 6. Effect of ABA concentrations on relative water content in the soil of Arabica coffee seedlings in water deficit condition. Vertical bars represent $\pm S D, n=8$

\section{CONCLUSION}

The foliar application of ABA reduced the growth and physiology traits of Arabica coffee seedlings in watering condition. However, the foliar application of ABA enhanced the drought tolerance in Arabica coffee seedlings by increasing the leaf chlorophyll value, Fv/Fm and relative water content in the leaves and decreasing the percentage of relative ion leakage. On the other hand, the application of ABA increased the relative water content in the soil and delayed the starting time of wilting point under water stress condition. From the results, it can be shown that $50 \mathrm{mgL}^{-1} \mathrm{ABA}$ is the optimal foliar concentration that can maintain of growth and physiology of Arabica coffee seedlings in water deficit condition.

\section{REFERENCES}

Agarwal, S., Sairam, R.K., Srivatava, G.C., Tyagi, A. \& Meena, R.C. 2005. Role of ABA, salicylic acid, calcium and hydrogen peroxide on antioxidant enzymes induction in wheat seedlings. Plant Science 169(3): 559-570.

Alves, A.A.C. \& Setter, T.L. 2000. Response of cassava to water deficit: Leaf area growth and abscisic acid. Crop Science 40(1): 131-137.

Anbarasi, G., Bhagavathi, G., Vignesh, R., Srinivasan, M. \& Somasundaram, S.T. 2015. Effect of exogenous abscisic acid on growth and biochemical changes in the halophyte Suaeda maritima. Journal of Microbiology, Biotechnology and Food Science 4(5): 442-447.

Ashraf, M. 2010. Inducing drought tolerance in plants: Some recent advances. Biotechnology Advances 28: 169-183.

Bakhsh, I., Awan, I., Sadiq, M., Niamatullah, M., Zaman, K.U. \& Aftab, M. 2011. Effect of plant growth regulator application at different growth stages on the economical yield potential of coarse rice (Oryza sativa L.). Journal of Animal and Plant Sciences 21(3): 612-616.

Borel, C., Simonneau, T., This, D. \& Tardieu, F. 1997. Stomatal conductance and $\mathrm{ABA}$ concentration in the xylem sap of barley lines of contrasting genetic origins. Australian Journal Plant Physiology 24(5): 607-615.

Carrow, R.N. 1996. Drought avoidance characteristics of diverse tall fescue cultivars. Crop Science 36(2): 371-377.

Cousson, A. 2009. Involvement of phospholipase C-independent calcium-mediated abscisic acid signaling during Arabidopsis response to drought. Biologia Plantarum 53(1): 53-62.

DaMatta, F.M. \& Ramalho, J.D.C. 2006. Impacts of drought and temperature stress on coffee physiology and production: A review. Brazilian Journal Plant of Physiology 18(1): 5581.

Farooq, U. \& Bano, A. 2006. Effects of abscisic acid and chlorocholine chloride on nodulation and biochemical content of Vigna radiata L. under water stress. Pakistan Journal Botany 38(5): 1511-1518.

Finkelstein, R.R., Gampala, S.S.L. \& Rock, C.D. 2002. Abscisic acid signaling in seeds and seedlings. Plant Cell 14: 15-45.

Franks, P.J. \& Farquhar, G.D. 2001. The effect of exogenous abscisic acid on stomatal development, stomatal mechanics, and leaf gas exchange in Tradescantia virginiana. Plant Physiology 125(2): 935-942.

Hala, E.M. \& Ghada, S.M.I. 2009. The role of abscisic acid in the response of two different wheat varieties to water deficit. Zeitschrift fur Naturforsch C 64(1-2): 77-84.

Hoagland, D.R. \& Arnon, D.I. 1950. The water-culture method for growing plants without soil. California Agricultural Experiment Station Circular 347: 1-32.

Jiang, Y. \& Huang, B. 2002. Protein alterations in tall fescue in response to drought stress and abscisic acid. Crop Science 42(1): 202-207. 
Larkindale, J. \& Knight, M.K. 2002. Protection against heat stress-induced oxidative damage in Arabidopsis involves calcium abscisic acid, ethylene, and salicylic acid. Plant Physiology 128(2): 682-695.

Leung, J. \& Giraudat, J. 1998. Abscisic acid signal transduction. Annual Review Plant Physiology and Plant Molecular Biology 49: 199-222.

Li, J., Wang, X.Q., Watson, M.B. \& Assmann, S.M. 2000. Regulation of abscisic acid-induced stomatal closure and anion channels by guard cell AAPK kinase. Science 287(5451): 300-303.

Li, X.J., Yang, M.F., Chen, H., Qu, L.Q., Chen, F. \& Shen, A.H. 2010. Abscisic acid pretreatment enhances salt tolerance of rice seedlings: Proteomic evidence. Biochimica et Biophysica Acta 1804(4): 929-940.

Ludewig, M., Dorffling, K. \& Seifert, H. 1988. Abscisic acid and water transport in sunflowers. Planta 175(3): 325-333.

Lu, G.H., Ren, D.L., Wang, X.Q., Wu, J.K. \& Zhao, M.S. 2010. Evaluation on drought tolerance of maize hybrids in China. Journal of Maize Sciences 2010(3): 20-24.

Munns, R. \& Cramer, G.R. 1996. Is coordination of leaf and root growth mediated by abscisic acid? Opinion. Plant and Soil 185(1): 33-49.

Pinheiro, H.A., DaMatta, F.M., Chaves, A.R.M., Loureiro, M.E. \& Ducatti, C. 2005. Drought tolerance is associated with rooting depth and stomatal control of water use in clones of Coffea canephora. Annals of Botany 96(1): 101-108.

Planes, M.D., Ninoles, R., Rubio, L., Bissoli, G., Bueso, E., Garcia-Sanchez, M.J., Alejandro, S., Gonzalez-Guzman, M., Hedrich, R., Rodriguez, P.L., Fernandez, J.A. \& Serrano, R. 2015. A mechanism of growth inhibition by abscisic acid in germinating seeds of Arabidopsis thaliana based on inhibition of plasma membrane $\mathrm{H}^{+}$ATPase and decreased cytosolic $\mathrm{pH}, \mathrm{K}^{+}$, and anions. Journal of Experimental Botany 66(3): 813-825.

Pospisilova, J., Synkova, H., Haisel, D. \& Batkova, P. 2009. Effect of abscisic acid on photosynthetic parameters during ex vitro transfer of micro propagated tobacco plantlets. Boilogia Plantarum 53(1): 11-20.

Pospisilova, J., Vagner, M., Malbeck, J., Travnıckova, A. \& Batkova, P. 2005. Interactions between abscisic acid and cytokinins during water stress and subsequent rehydration. Boilogia Plantarum 49(4): 533-540.

Rajasekaran, L.R. \& Blake, T.J. 1999. New plant growth regulators protect photosynthesis and enhance growth under drought of jack pine seedlings. Journal of Plant Growth Regulation 18(4): 175-181.

Sewelam, N., Dowidar, S., Abo-Kassem, E.A. \& Sobhy, S. 2017. Study of the interactive effects of calcium and abscisic acid on drought stressed Triticum aestivum seedlings. Egyptian Journal of Botany 57(7th International conference): 215-232.
Sharp, R.E., Wu, Y., Voetberg, G.S., Saab, I.N. \& LeNoble, M.E. 1994. Confirmation that abscisic acid accumulation is required for maize primary root elongation at low water potentials. Journal of Experimental Botany 45(Special issue): 1743-1751.

Taylor, I.B., Burbidge, A. \& Thompson, A.J. 2000. Control of abscisic acid synthesis. Journal of Experimental Botany 51(350): 1563-1574.

Vu, N.T., Kang, H.M., Kim, Y.S., Choi, K.Y. \& Kim, I.S. 2015. Growth, physiology and abiotic stress response to abscisic acid in tomato seedlings. Horticulture, Environment, and Biotechnology 56(3): 294-304.

Wang, S.H., Sui, X.L., Hu, L.P., Sun, J.L., Wei, Y.X. \& Zhang, Z.X. 2010. Effects of exogenous abscisic acid pre-treatment of cucumber (Cucumis sativus) seeds on seedling growth and water-stress tolerance. New Zealand Journal of Crop and Horticultural Science 38(1): 7-18.

Waterland, N.L., Finer, J.J. \& Jones, M.L. 2010. Abscisic acid applications decrease stomatal conductance and delay wilting in drought-stressed chrysanthemums. HortTechnology 20(5): 896-901.

Wintgens, J.N. 2004. Coffee: Growing, Processing, Sustainable Production. A Guidebook for Growers, Processors, Traders, and Researchers. Weinhem: Wiley-VCH Verlag GmbH \& Co.

Zhang, J.H., Zhang, X.P. \& Liang, J.S. 1995. Exudation rate and hydraulic conductivity of maize roots are enhanced by soil drying and abscisic acid treatment. New Phytologist 131(3): 329-336.

Zhao, M.G., Zhao, X., Wu, Y.X. \& Zhang, L.X. 2007. Enhanced sensitivity to oxidative stress in an Arabidopsis nitric oxide synthase mutant. Journal of Plant Physiology 164(6): 737 745 .

Ngoc-Thang Vu \& Anh-Tuan Tran

Faculty of Agronomy

Vietnam National University of Agriculture, Hanoi

Vietnam

Jong-Man Park, Il-Soep Kim \& Dong-Cheol Jang* Department of Horticulture

Kangwon National University

Chuncheon 200-701

Korea

*Corresponding author; email: jdc@kangwon.ac.kr

Received: 15 September 2019

Accepted: 13 March 2020 